Article

\title{
Biotechnology and Bioprocesses: Their Contribution to Sustainability
}

\author{
Alejandro Barragán-Ocaña ${ }^{1, * \mathbb{C}}$, Paz Silva-Borjas ${ }^{1}{ }^{1}$, Samuel Olmos-Peña ${ }^{2}$ \\ and Mirtza Polanco-Olguín ${ }^{1}$ \\ 1 Instituto Politécnico Nacional (IPN), Centro de Investigaciones Económicas, Administrativas y \\ Sociales (CIECAS), Lauro Aguirre 120. Col. Agricultura, Alcaldía. Miguel Hidalgo, \\ Ciudad de México C. P. 11360, Mexico; psilva@ipn.mx (P.S.-B.); mpolancoo@ipn.mx (M.P.-O.) \\ 2 Universidad Autónoma del Estado de México (UAEM), Centro Universitario UAEM Valle de Chalco, \\ Hermenegildo Galena No.3, Colonia María Isabel, Valle de Chalco CP, Estado de México 56615, Mexico; \\ solmosp@uaemex.mx \\ * Correspondence: abarragano@ipn.mx; Tel.: +52-5557-296-000
}

Received: 21 March 2020; Accepted: 2 April 2020; Published: 7 April 2020

check for updates

\begin{abstract}
Significant advancements in biotechnology have resulted in the development of numerous fundamental bioprocesses, which have consolidated research and development and industrial progress in the field. These bioprocesses are used in medical therapies, diagnostic and immunization procedures, agriculture, food production, biofuel production, and environmental solutions (to address water-, soil-, and air-related problems), among other areas. The present study is a first approach toward the identification of scientific and technological bioprocess trajectories within the framework of sustainability. The method included a literature search (Scopus), a patent search (Patentscope), and a network analysis for the period from 2010 to 2019. Our results highlight the main technological sectors, countries, institutions, and academic publications that carry out work or publish literature related to sustainability and bioprocesses. The network analysis allowed for the identification of thematic clusters associated with sustainability and bioprocesses, revealing different related scientific topics. Our conclusions confirm that biotechnology is firmly positioned as an emerging knowledge area. Its dynamics, development, and outcomes during the study period reflect a substantial number of studies and technologies focused on the creation of knowledge aimed at improving economic development, environmental protection, and social welfare.
\end{abstract}

Keywords: bioeconomy; bioprocesses; applications; policy; social welfare; sustainability

\section{Introduction}

Biotechnology and bioprocesses are two important tools for economic progress and social welfare. The industrial, academic, and government sectors are bound to face technical problems as they develop competitive biotechnological products and processes using synthetic biology, genetics, and molecular biology as alternatives to chemical-based applications. In this regard, the biological control of microbial consortia based on synthetic biology solutions and the regulation and optimization of the migration from batch production to continuous production are ongoing tasks [1,2]. In the biopharmaceutical industry, improved bioprocesses are always in demand to address new regulatory requirements, quality control needs, and production problems in biological products, cell culture titration, and the production of biosimilars [3-5].

Applications derived from biotechnology are very diverse, including food design, processing, and optimization to improve nutritional intake [6]; the optimization of processes to purify monoclonal antibodies for the treatment of different conditions, the analysis of host cell proteins (HCPs), 
and the production of hematopoietic stem cells (HSCs) for therapeutic purposes [7-9]; the development of microorganisms for the processing and transformation of biomass into fuels [10-12]; the production of raw materials based on fermentation processes, such as ethanol, butanol [13-15], and other products traditionally derived from chemical sources, such as aliphatic, aromatic, and other macromolecules using bioprocesses, such as (a) separate hydrolysis and fermentation (SHF), (b) simultaneous saccharification and fermentation (SSF), and (c) consolidated bioprocessing (CBP) [16]; and the construction of bioelectronic devices for applications in multivariate data analysis, experiment design, mathematical models, sensors, and biosensors whose data are processed by software to monitor and optimize processes [17-22].

Other important bioprocesses involve the large-scale production of secondary metabolites relevant for the food, cosmetics, pharmaceutical [23], wastewater treatment, and bioremediation industries (all of these are high-value processes) using bacteria and plant cells produced in vitro to protect endangered or scarce plants or to obtain metabolites $[24,25]$ and enzymes produced by filamentous fungi, leveraging the advances of genetic engineering and molecular biology [26]; the development of cells that can be used in the production of new drugs [27]; the application of enzymatic processes to treat textiles [28]; the use of bacteria for the production of enzymes and various chemical products [29]; the use of nanotechnology, for instance, the nano-encapsulation of bioactive compounds, intelligent packaging systems in food production, biocatalysts and biosensors, and microbiological identification [30,31]; the collection and commercialization of recyclable and biodegradable biopolymers such as PLA (polylactide) [32]; and the development of regenerative medicine solutions [33].

Culture collections (CCs) and microbial biological resources centers (mBRCs) are two critical elements during the microorganism characterization and preservation process. In the second case, in spite of pending challenges, Europe has achieved substantial progress in the areas of databases, quality, infrastructure, legislation, and project development. This progress contributes to the preservation of biodiversity and ecosystems and, certainly, to stimulating the innovation, research, and development of biotechnology-based applications [34,35]. Molecular and genetic characterizations of living collections of biological resources provide added value to these biorepositories. As a consequence, their development has technical, financial, and regulatory implications to address depending on the type of collection (microbial cultures and animal or plant germplasm) [36].

Acetic acid bacteria are an interesting group of organisms with potential for the generation of diverse metabolites of industrial application based on sustainable processes; however, current processes still have limitations to address large-scale industrial demand [37]. Another example is the development of yeasts that produce high amounts of glutathione to be used in drugs, cosmetics, and foods; in the wine production industry, the antioxidant effect of glutathione and its action against unwanted aromatic compounds are particularly adequate [38].

As can be appreciated, the impact of biotechnology on social welfare is evident and has been widely discussed. Areas of focus such as sustainability, the decrease in $\mathrm{CO}_{2}$ emissions, technological change, and the bioeconomy are associated with this field of study, whose potential is vital for the development of numerous products based on inputs derived from agriculture or other renewable sources of biological origin [39-41]. For example, marine algae can be used to produce biofuels and bioenergy as a substitute for fossil fuels [42,43]. In the case of genetically modified and improved seeds, potential risks and benefits are the subject of heated debate, especially around the ethics of their development and use, and the issues related to economic and environmental impact have yet to be addressed [44,45]. It is also possible to use materials created by biological agents or to use these agents in environmental remediation applications [46]. This new reality underscores the need to analyze the peculiarities of these inventions in order to address their resulting intellectual property rights adequately [47].

Thus, under an full (economic, social, and environmental) approach, concerned with social welfare and the development of the bioeconomy, sustainability is closely oriented toward achieving objectives and promoting economic growth $[48,49]$. Although all of these biological resources are renewable 
and the solutions that they provide are socially valuable, it is essential to respect and preserve their biological sources and optimize the use of water and energy to carry out the bioprocesses. As a consequence, the use of environmental indicators (climate change, water, energy, land use, chemical risk) is necessary to manage resources sustainably [50]. However, evaluating the social impact of these advances is one of the most neglected tasks in the field of bioeconomics because the attention has been focused on environmental and techno-economic elements [51]. Additionally, the adverse effects of globalization on economic equality and the preservation of biodiversity must be considered in each case and context and paying attention to social indicators related to health, food, and employment, among others, must be paramount [52-54].

Biotechnology uses bioprocesses as an operating mechanism, and the development and improvement of these processes provide technological alternatives to solve myriad problems in the health, food, energy, agriculture, and many other industrial sectors. As a result, academia, the business sector, governments, non-governmental organizations, and the societies in which all these applications have a positive economic, social, or environmental impact have taken an interest in bioprocesses. Nevertheless, the alternatives brought forth by the bioeconomy to promote economic development should not be limited to technological advancement per se but include other aspects of interest to different actors.

Specifically, the emphasis must be placed on developments that support social welfare and mitigate environmental impact. Although technologically and economically efficient solutions to address environmental and other types of technical issues that represent a significant social impact are already being developed, it is also true that many challenges have to do with the creation of policies, regulations, and ethical guidelines concerning biosecurity, as well as with technical and risk assessments, industrial scale-up, the efficient use of renewable resources, and industry-driven ad hoc mechanisms to address specific problems derived from this area of application (see Figure 1).

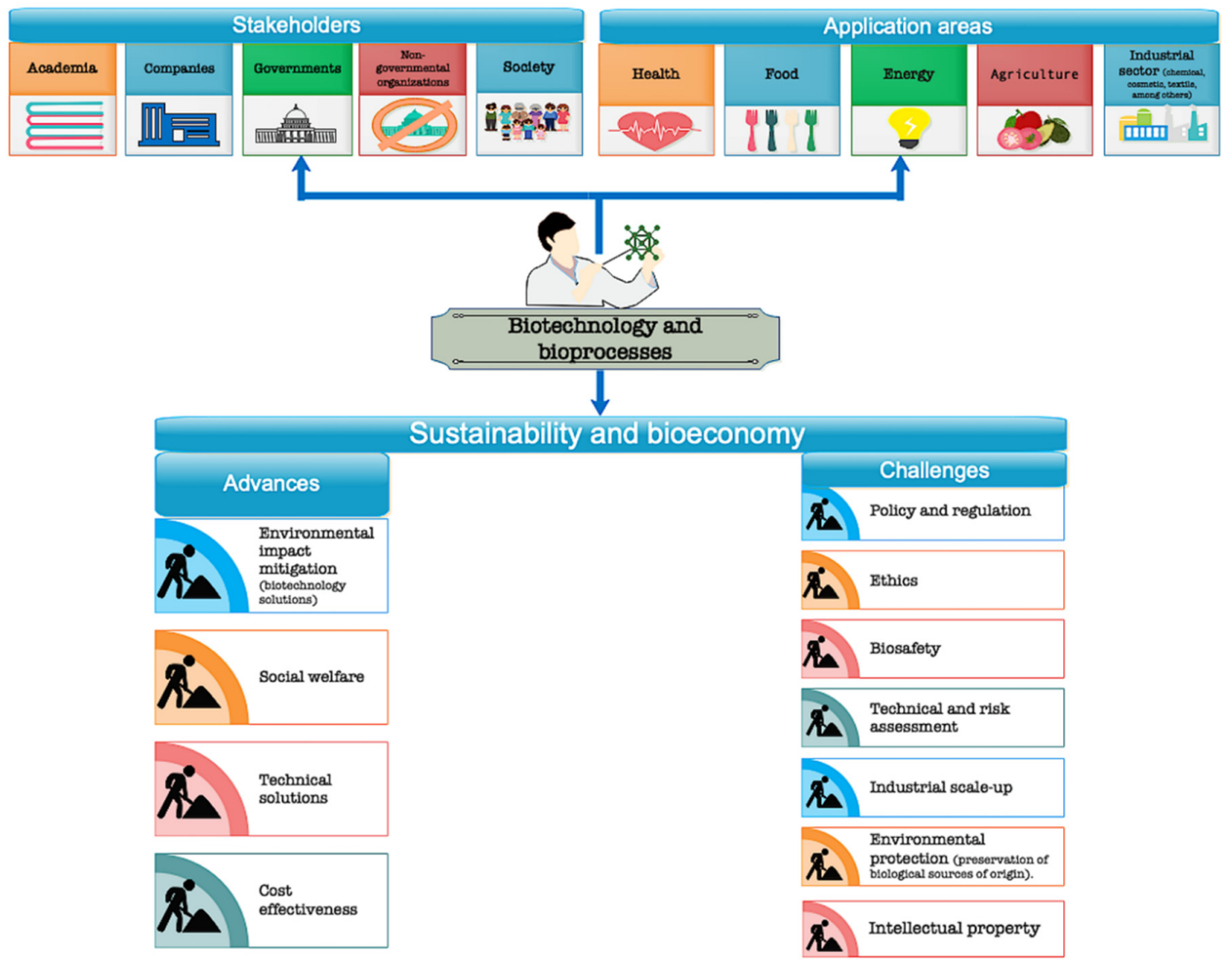

Figure 1. Bioeconomy, biotechnology, and sustainability. Source: elaborated by the authors. 


\section{Method}

A literature search and a patent application search were carried out using the Scopus (in the case of Scopus, the search criterion was as follows: (TITLE-ABS-KEY (bioproce*) AND TITLE-ABS-KEY $($ sustainab*)) AND PUBYEAR > 2009) [55] and Patentscope (in the case of Patentscope, the advanced search criteria for English language in all offices was: bioproce* AND sustainab*) [56] databases, respectively, for the period from 2010 to 2019, as a first approach to understand the relationship between sustainability and bioprocess. The purpose of the present study was to identify documents and patent applications related to the development and analysis of sustainability involving bioprocesses to approach our object of study along the economic, social, and environmental axes. In addition, the search sought to reveal an initial outline of the scientific and technological trajectories around these terms during the study period.

Thus, the first of these databases identified the 676 most relevant publications by country, knowledge area, institution, and source; the lowest number of published documents (29) corresponded to 2010, whereas the highest (103) corresponded to 2018. Concerning the patent search, the data considered were the number of applications per country, per institution, and technology area; 1233 applications were found, and 2013 was the year with the most significant number of applications (156). The data obtained from Scopus were subjected to network analysis, including co-occurrence, using the authors' keywords as a unit of analysis and full counting. Additionally, a co-authorship study was included in the analysis, considering the country as a unit of analysis and full counting.

\section{Results}

Figure 2 shows that the United States was the leader in bioprocess and sustainability-related research during the study period. Among the ten leading countries, India, China, and Germany published more than 50 documents each. The most developed areas, those with more than 100 documents, were biochemistry, genetics, and molecular biology; chemical engineering; immunology and microbiology; environmental science; energy and engineering. These data highlight the need to increase the number of basic research projects in disciplines focused on the development or improvement of new bioprocesses and their industrial scale-up and the creation of technological applications for the medical, food, environmental, and power generation sectors.

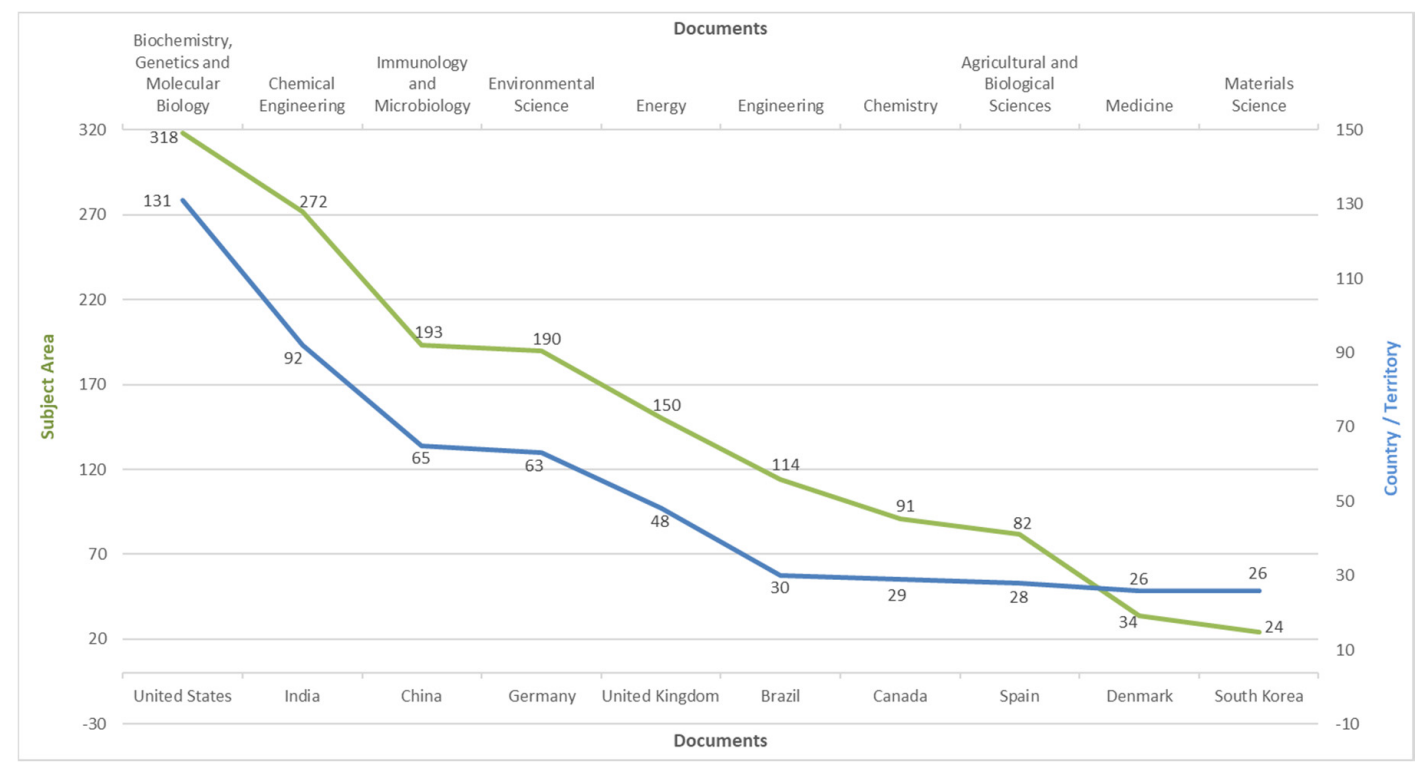

Figure 2. Documents by area of knowledge and country (2010-2019). Source: elaborated by the authors based on Scopus [55]. 
According to Journal Citation Reports (JCR) [57] 2018, two important academic journals led the list with more than 30 published documents: (1) Bioresource Technology, with an impact factor of 6.669 and ranked Q1 in the following three areas: (a) Agricultural Engineering, (b) Biotechnology and Applied Microbiology, and (c) Energy and Fuels; and (2) Applied Microbiology and Biotechnology, with an impact factor of 3.670 and ranked Q2 in Biotechnology and Applied Microbiology. They are followed by journals with ten or more published documents: Biotechnology for Biofuels (impact factor: 5.452); Biotechnology and Bioengineering (impact factor: 4.260); Current Opinion in Biotechnology (impact factor: 8.083); Renewable and Sustainable Energy Reviews (impact factor: 10.556); Journal of Chemical Technology and Biotechnology (impact factor: 2.659); and Biotechnology Journal (impact factor: 3.543) (the quartiles for the rest of the journals with at least 10 documents are distributed according to different categories as follows: (1) Biotechnology for Biofuels: Biotechnology and Applied Microbiology (Q1) and Energy and Fuels (Q1); (2) Biotechnology and Bioengineering: Biotechnology and Applied Microbiology (Q1); (3)- Current Opinion in Biotechnology: Biochemical Research Methods (Q1) and Biotechnology and Applied Microbiology (Q1); (4) Renewable and Sustainable Energy Reviews: Green and Sustainable Science and Technology (Q1) and Energy and Fuels (Q1); (5) Journal of Chemical Technology and Biotechnology: Biotechnology and Applied Microbiology (Q2), Chemistry, Multidisciplinary (Q2), Engineering, Environmental (Q3), Engineering, Chemical (Q2); and (6) Biotechnology Journal: Biochemical Research Methods (Q1) and Biotechnology and Applied Microbiology (Q2).) These top ten journals include the participation of institutions from Denmark, the Netherlands, England, France, the United States, Korea, India, and Brazil (see Figure 3).

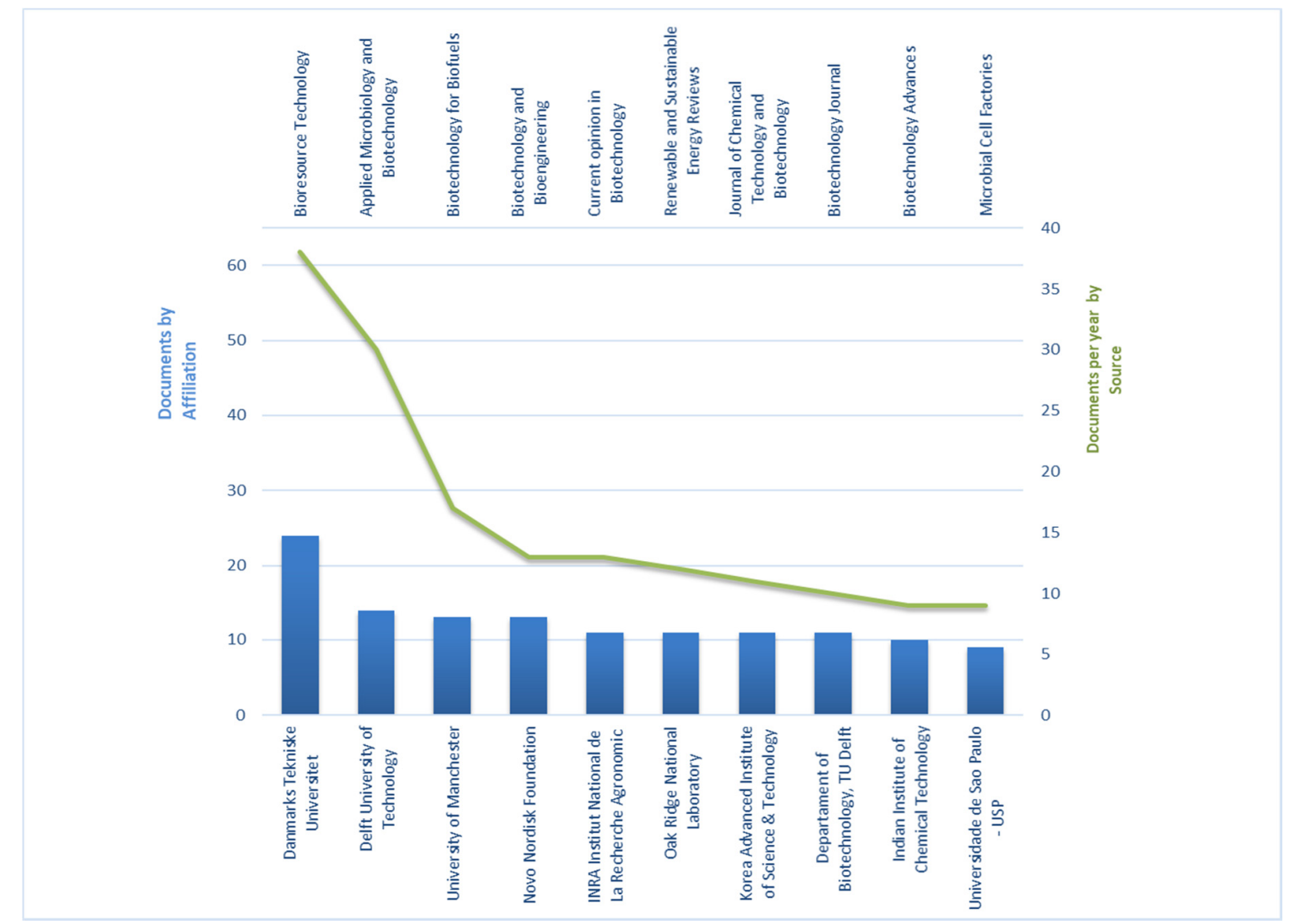

Figure 3. Documents by affiliation and source of publication (2010-2019). Source: elaborated by the authors based on Scopus [55].

In regard to technological development, patent applications were clearly dominated by the United States, where 552 applications were filed. This country was followed by the Patent Cooperation Treaty (PCT), Australia, and the European Patent Office, with more than 100 applications each. By institution, 
Genomatica, Inc. ranked first with 118 applications, followed by Regents of the University of California with 44, and the Massachusetts Institute of Technology with 35; all of these institutions are based in the United States. The participation of independent inventors and another American company are noteworthy. These data show that the United States, Australia, and European countries are the target market for this type of invention, according to the data obtained by searching in English (see Figure 4).

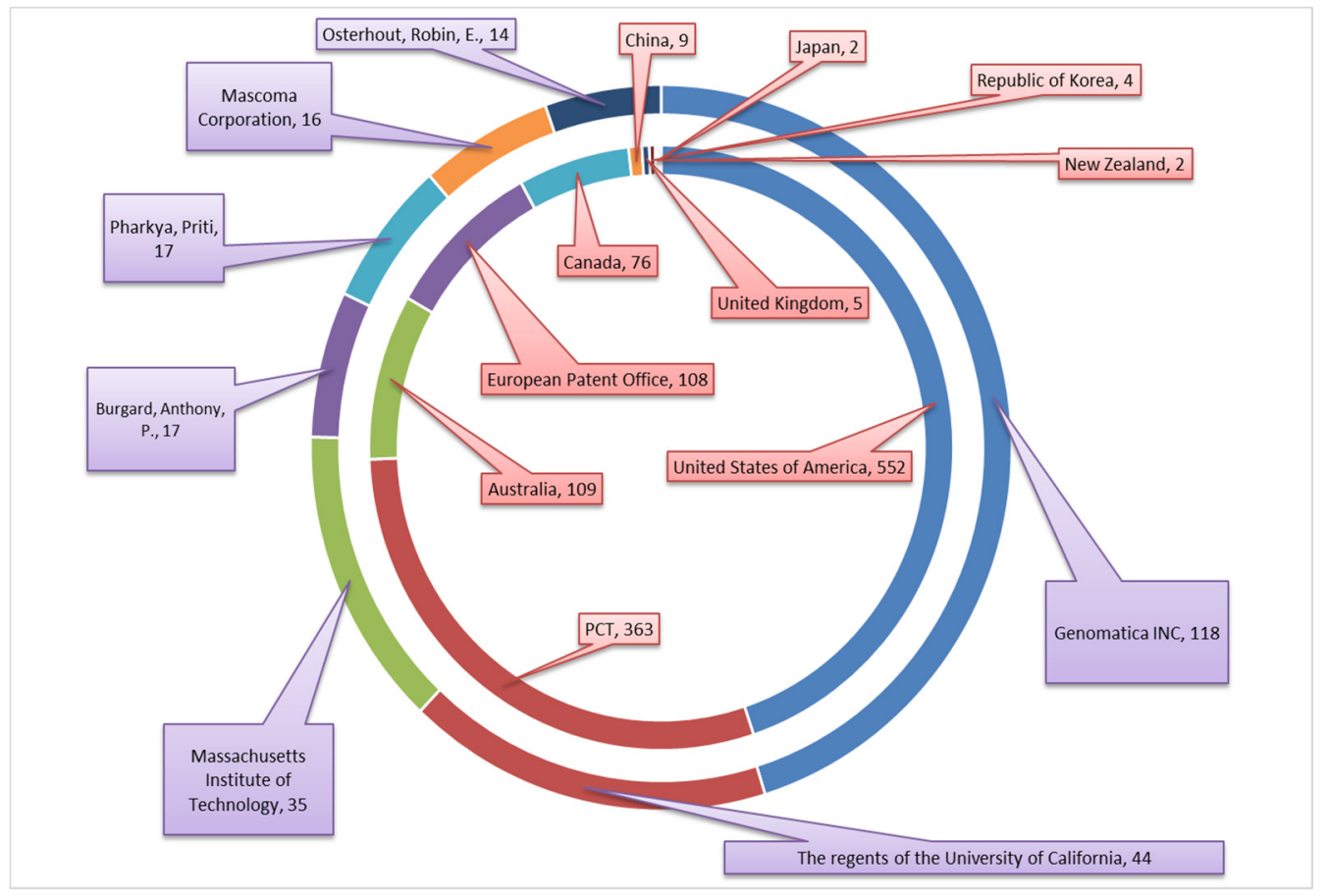

Figure 4. Patent applications by country and institution (2010-2019). Source: elaborated by the authors based on World Intellectual Property Organization (WIPO) [56].

Most of these applications are related to scientific and technological areas of traditional expertise in the development of bioprocesses, fermentation processes, the use of enzymes to obtain various chemical compounds, and other formulations and applications involving microorganisms or enzymes, in addition to compositions of microorganisms and enzymes that are essential in many applications and processes. The rest of the categories are related to the development of new devices; the manufacture of organic compounds and pharmaceutical products; medical appliances; the production of deodorization, disinfection, and sterilization materials; indexing associated with other microorganism subclasses; applications related to water treatment, wastewater, sewage, and sludges; peptide generation processes; separation methods, and applications associated with sugars, sugar derivatives, nucleosides, nucleic acids, and nucleotides, among other examples (see Table 1).

The network analysis based on the literature search showed that sustainability and bioprocesses are central points in this search; both keywords are grouped in the largest cluster, together with smaller nodes such as green chemistry, enzymes, biocatalysis, and industrial biotechnology, among others. Around this cluster, the figure shows three smaller groupings, whose main nodes are as follows: (1) fermentation, biofuels, bioethanol, biorefining, and lignocellulose; (2) microalgae, anaerobic digestion, bioenergy, biodiesel, biohydrogen, and dark fermentation; and (3) consolidated bioprocessing, biofuel, biobutanol, and clostridium. Finally, a smaller cluster, whose main component is associated with synthetic biology, can also be appreciated. These links showcase the vigorous dynamics of bioprocess design research in connection with sustainability. They outline where most of the scientific research is taking place and where the new areas of opportunity originating around this activity can be found (see Figure 5). 
Table 1. Patent applications by technological field (2010-2019).

\begin{tabular}{cccc}
\hline No. & Code & Classification & Number \\
\hline 1 & C12P & $\begin{array}{c}\text { Fermentation or enzyme-using processes to synthesize } \\
\text { a desired chemical compound or composition or to separate } \\
\text { optical isomers from a racemic mixture. }\end{array}$ & 735 \\
\hline 2 & C12N & $\begin{array}{c}\text { Microorganisms or enzymes . . ; compositions thereof . . } \\
\text { propagating, preserving, or maintaining microorganisms; } \\
\text { mutation or genetic engineering; culture media ... }\end{array}$ & 623 \\
\hline 3 & C12M & Apparatus for enzymology or microbiology ... & 114 \\
\hline 4 & C07C & Acyclic or carbocyclic compounds ... & 82 \\
\hline 5 & A61K & Preparations for medical, dental, or toilet purposes ... & 81 \\
\hline 6 & C12R & $\begin{array}{c}\text { Indexing scheme associated with subclasses ... } \\
\text { relating to microorganisms }\end{array}$ & 78 \\
\hline 7 & C02F & Treatment of water, wastewater, sewage, or sludge ... & 76 \\
\hline 8 & C07K & Peptides ... & 54 \\
\hline 9 & B01D & Separation & 47 \\
\hline 10 & C07H & Sugars; derivatives thereof; nucleosides; nucleotides; \\
\hline
\end{tabular}

Source: elaborated by the authors based on WIPO [56,58].

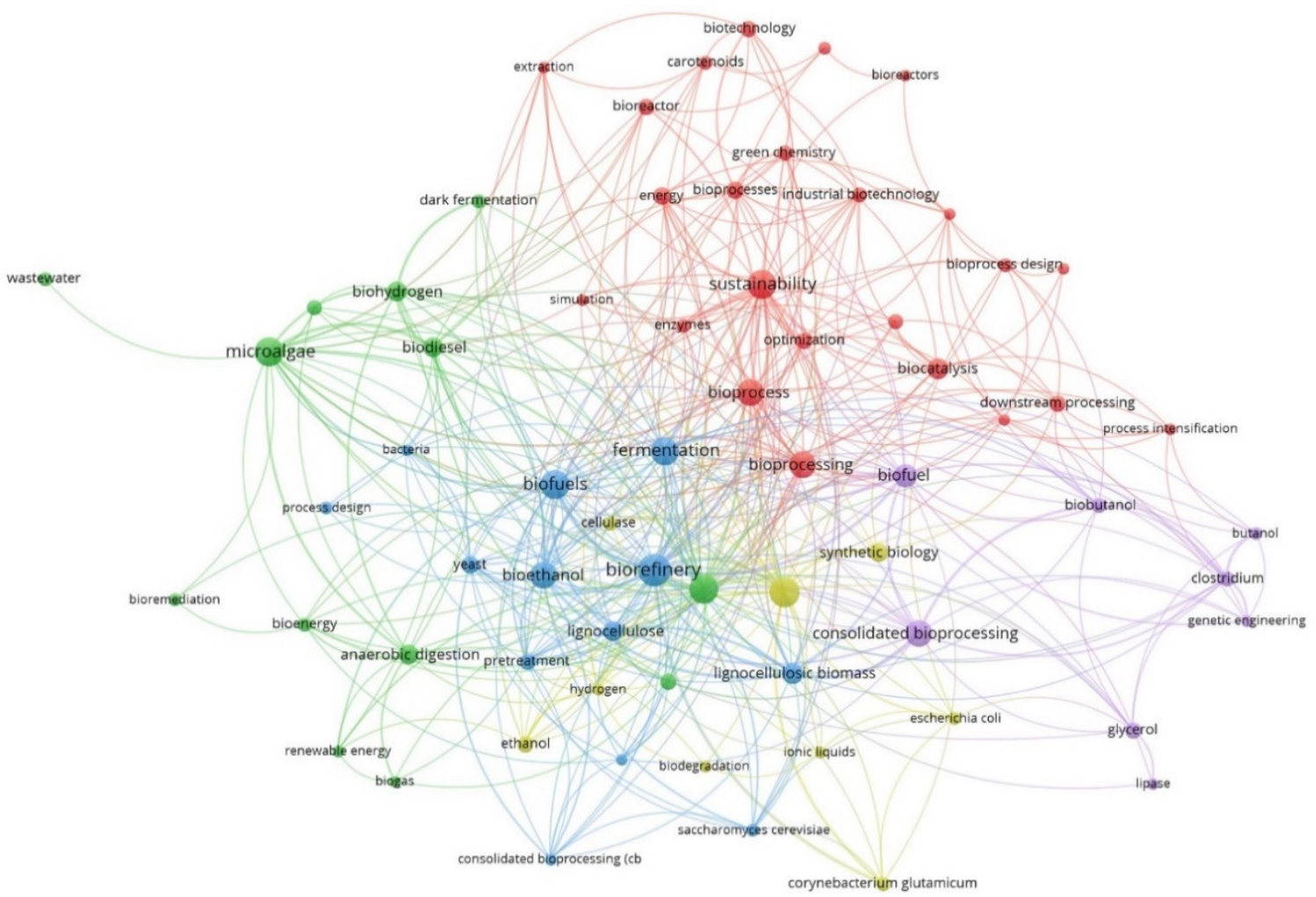

Figure 5. Keyword co-occurrence analysis: (author)-full counting. Source: elaborated by the authors based on Scopus [55].

As mentioned before, the United States was determined to be the primary originator of publications focused on sustainability and bioprocesses, and the same was valid for institutional collaboration. However, although with lower frequency and proximity, the presence of other economies such as India, Germany, China, England, South Africa, Mexico, Chile, Malaysia, Australia, Turkey, Italy, 
and Singapore, among others, could also be observed in the network; individually, these countries connected to different clusters. Therefore, it is necessary to increase our efforts to generate new research focused on the sustainability of bioprocesses in local environments in collaboration with scientists from institutions in different parts of the world, since biotechnological solutions cannot always be applied globally, hence the need for ad hoc solutions to specific problems, especially in developing countries (see Figure 6).

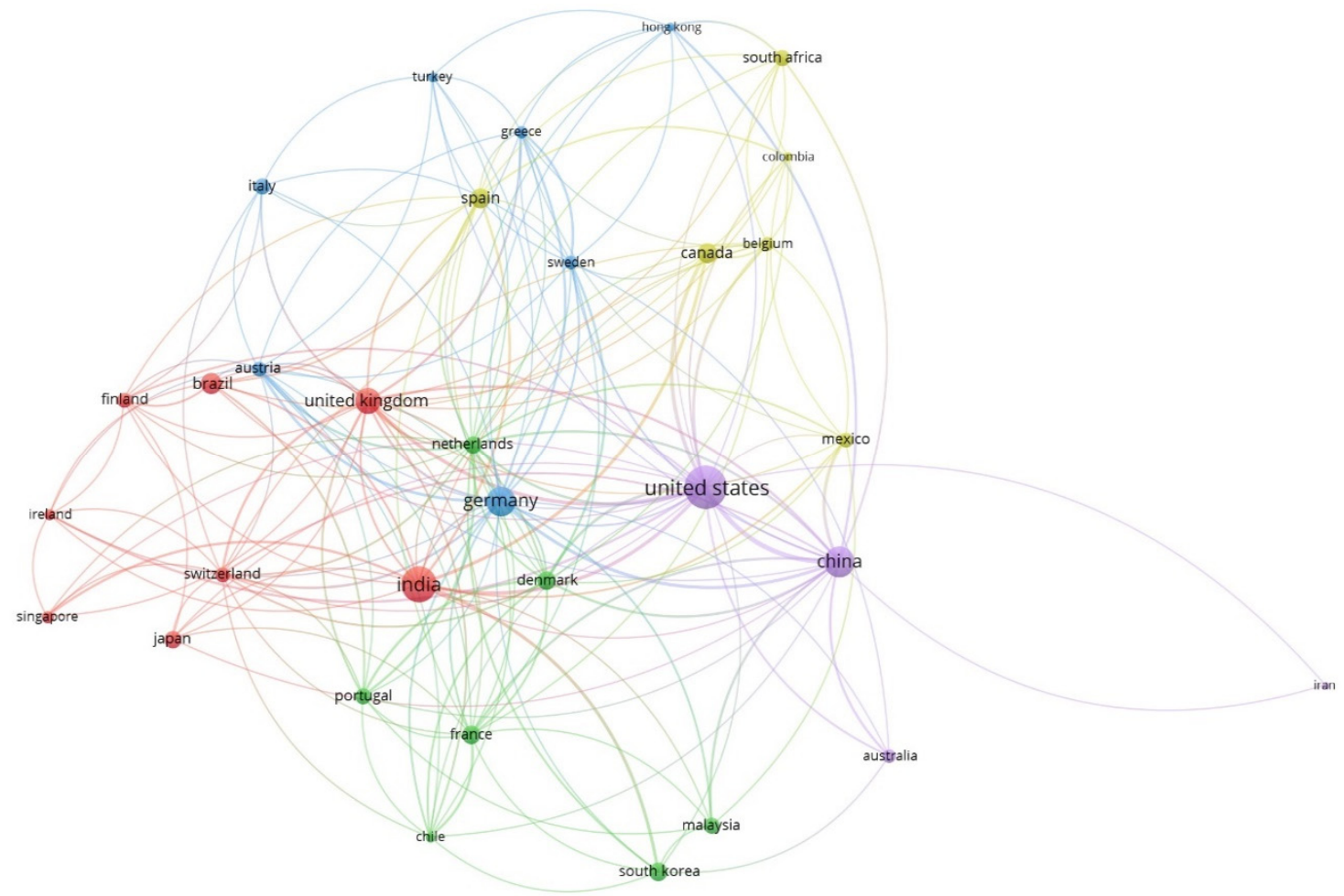

Figure 6. Co-authorship analysis: country-full counting. Source: elaborated by the authors based on Scopus [55].

\section{Conclusions}

Biotechnology has provided society with thousands of bioprocesses to address diseases and food demands, to develop petroleum product substitutes, to provide alternatives for energy production, and to solve agricultural problems, among other benefits. Applications and products based on biological sources are the framework of a bioeconomy that contributes to the economic development of regions and countries. However, social welfare and care for the environment must be inherent to these applications, which is why the generation of ad hoc indicators of these two areas is necessary to monitor these areas.

The scientific and technological trajectory shows how sustainability and bioprocesses are topics of great interest and constantly growing, although further efforts are still needed to move toward an integrated sustainability framework. Microbiology and enzymology are often prevalent in this technological field, although new areas of opportunity are emerging around the new demand for sustainable solutions to support economic growth and industrial development, especially basic science projects, which need to be explored and exploited in greater depth. New bioprocesses based on biorefining, bioethanol, consolidated bioprocessing, microalgae, lignocellulose, biocatalysis, and biohydrogen are among the products and technologies of the future.

In the following decades, actors from the academic, business, and government sectors, in addition to non-governmental organizations and society in general, will have to intensify their collaboration mechanisms, especially in developing economies, where the challenge to move forward 
sustainably is harder and problems associated with poverty and inequality tend to be more serious. Although biotechnology has shown unprecedented progress, it is also true that the design of bioprocesses must be geared to sustainability criteria, in which social impact must be a priority. Additional aspects to take into account to guarantee the successful development of future biotechnological applications for the benefit of economic development, environmental protection, and social welfare are legislative, normative, and ethical considerations; the optimization of resources and the conservation of biological sources; technical and risk assessment; biosecurity, and intellectual property.

Author Contributions: Conceptualization and methodology: A.B.-O. and P.S.-B.; Investigation: A.B.-O., P.S.-B., S.O.-P. and M.P.-O.; Formal Analysis: A.B.-O., P.S.-B. and S.O.-P.; Data curation: P.S.-B., S.O.-P. and M.P.-O. All authors have read and agreed to the published version of the manuscript.

Funding: SIP grant numbers 20195587 and 20200773.

Acknowledgments: We wish to acknowledge the support provided by the National Polytechnic Institute (Instituto Politécnico Nacional-IPN) and the Secretariat for Research and Postgraduate Studies (Secretaría de Investigación y Posgrado-SIP).

Conflicts of Interest: The authors declare no conflict of interest.

\section{References}

1. Croughan, M.S.; Konstantinov, K.B.; Cooney, C. The Future of Industrial Bioprocessing: Batch or Continuous? Biotechnol. Bioeng. 2015, 112, 648-651. [CrossRef]

2. Shong, J.; Jimenez Diaz, M.R.; Collins, C.H. Towards synthetic microbial consortia for bioprocessing. Curr. Opin. Biotechnol. 2012, 23, 798-802. [CrossRef] [PubMed]

3. Whitford, W.G. Single-use technology supporting the comeback of continuous bioprocessing. Pharm. Bioprocess. 2013, 1, 249-253. [CrossRef]

4. Cramer, S.M.; Holstein, M.A. Downstream bioprocessing: Recent advances and future promise. Curr. Opin. Chem. Eng. 2011, 1, 27-37. [CrossRef]

5. Wuest, D.M.; Harcum, S.W.; Lee, K.H. Genomics in mammalian cell culture bioprocessing. Biotechnol. Adv. 2012, 30, 629-638. [CrossRef]

6. Jägerstad, M.; Piironen, V.; Walker, C.; Ros, G.; Carnovale, E.; Holasova, M.; Nau, H. Increasing natural food folates through bioprocessing and biotechnology. Trends Food Sci. Technol. 2005, 16, 298-306. [CrossRef]

7. Levy, N.E.; Valente, K.N.; Choe, L.H.; Lee, K.H.; Lenhoff, A.M. Identification and characterization of host cell protein product-associated impurities in monoclonal antibody bioprocessing. Biotechnol. Bioeng. 2014, 111, 904-912. [CrossRef]

8. Tscheliessnig, A.L.; Konrath, J.; Bates, R.; Jungbauer, A. Host cell protein analysis in therapeutic protein bioprocessing-Methods and applications. Biotechnol. J. 2013, 8, 655-670. [CrossRef]

9. Kelley, B. Industrialization of $\mathrm{mAb}$ production technology: The bioprocessing industry at a crossroads. $m A b s$ 2009, 1, 443-452. [CrossRef]

10. Lynd, L.E.; van Zyl, W.H.; McBride, J.E.; Laser, M. Consolidated bioprocessing of cellulosic biomass: An update. Curr. Opin. Biotechnol. 2005, 16, 577-583. [CrossRef]

11. Jin, M.; Balan, V.; Gunawan, C.; Dale, B.E. Consolidated bioprocessing (CBP) performance of clostridium phytofermentans on AFEX-treated corn stover for ethanol production. Biotechnol. Bioeng. 2011, 108, 1290-1297. [CrossRef] [PubMed]

12. Parisutham, V.; Kim, T.H.; Lee, S.K. Feasibilities of consolidated bioprocessing microbes: From pretreatment to biofuel production. Bioresour. Technol. 2014, 161, 431-440. [CrossRef] [PubMed]

13. Blanch, H.W. Bioprocessing for biofuels. Curr. Opin. Biotechnol. 2012, 23, 390-395. [CrossRef] [PubMed]

14. Yuan, W.J.; Chang, B.L.; Ren, J.G.; Liu, J.P.; Bai, F.W.; Li, Y.Y. Consolidated bioprocessing strategy for ethanol production from Jerusalem artichoke tubers by Kluyveromyces marxianus under high gravity conditions. J. Appl. Microbiol. 2012, 112, 38-44. [CrossRef]

15. Favaro, L.; Jansen, T.; Van Zyl, W.H. Exploring industrial and natural Saccharomyces cerevisiae strains for the bio-based economy from biomass: The case of bioethanol. Crit. Rev. Biotechnol. 2019, 39, 800-816. [CrossRef] 
16. Kawaguchi, H.; Hasunuma, T.; Ogino, C.; Kondo, A. Bioprocessing of bio-based chemicals produced from lignocellulosic feedstocks. Curr. Opin. Biotechnol. 2016, 42, 30-39. [CrossRef]

17. Yang, B.X.; Kim, E.; Liu, Y.; Shi, X.W.; Rubloff, G.W.; Ghodssi, R.; Bentley, W.E.; Pancer, Z.; Payne, G.F. In-film bioprocessing and immunoanalysis with electroaddressable stimuli-responsive polysaccharides. Adv. Funct. Mater. 2010, 20, 1645-1652. [CrossRef]

18. Lim, M.; Ye, H.; Panoskaltsis, N.; Drakakis, E.M.; Yue, X.; Cass, A.E.G.; Radomska, A.; Mantalaris, A. Intelligent bioprocessing for haemotopoietic cell cultures using monitoring and design of experiments. Biotechnol. Adv. 2007, 25, 353-368. [CrossRef]

19. Kirdar, A.O.; Green, K.D.; Rathore, A.S. Application of multivariate data analysis for identification and successful resolution of a root cause for a bioprocessing application. Biotechnol. Prog. 2008, 24, 720-726. [CrossRef]

20. Kumar, V.; Bhalla, A.; Rathore, A.S. Design of experiments applications in bioprocessing: Concepts and approach. Biotechnol. Prog. 2014, 30, 86-99. [CrossRef]

21. Randek, J.; Mandenius, C.F. On-line soft sensing in upstream bioprocessing. Crit. Rev. Biotechnol. 2018, 38, $106-121$. [CrossRef] [PubMed]

22. Dekker, L.; Polizzi, K.M. Sense and sensitivity in bioprocessing-Detecting cellular metabolites with biosensors. Curr. Opin. Chem. Biol. 2017, 40, 31-36. [CrossRef] [PubMed]

23. Steingroewer, J.; Bley, T.; Georgiev, V.; Ivanov, I.; Lenk, F.; Marchev, A.; Pavlov, A. Bioprocessing of differentiated plant in vitro systems. Eng. Life Sci. 2013, 13, 26-38. [CrossRef]

24. Georgiev, M.I.; Weber, J.; Maciuk, A. Bioprocessing of plant cell cultures for mass production of targeted compounds. Appl. Microbiol. Biotechnol. 2009, 83, 809-823. [CrossRef] [PubMed]

25. Zaidi, K.U.; Ali, A.S.; Ali, S.A.; Naaz, I. Microbial tyrosinases: Promising enzymes for pharmaceutical, food bioprocessing, and environmental industry. Biochem. Res. Int. 2014, 2014, 854687. [CrossRef] [PubMed]

26. Wang, L.; Ridgway, D.; Gu, T.; Moo-Young, M. Bioprocessing strategies to improve heterologous protein production in filamentous fungal fermentations. Biotechnol. Adv. 2005, 23, 115-129. [CrossRef]

27. Thomson, H. Bioprocessing of embryonic stem cells for drug discovery. Trends Biotechnol. 2007, 25, $224-230$. [CrossRef] [PubMed]

28. Mojsov, K.D. Trends in bio-processing of textiles: A review. Adv. Technol. 2014, 3, 135-138. [CrossRef]

29. Pfeifenschneider, J.; Brautaset, T.; Wendisch, V.F. Methanol as carbon substrate in the bio-economy: Metabolic engineering of aerobic methylotrophic bacteria for production of value-added chemicals. Biofuels Bioprod. Bioref. 2017, 11, 719-731. [CrossRef]

30. Neethirajan, S.; Jayas, D.S. Nanotechnology for the food and bioprocessing industries. Food Bioprocess. Technol. 2011, 4, 39-47. [CrossRef]

31. Trujillo, L.E.; Ávalos, R.; Granda, S.; Guerra, L.S.; País-Chanfrau, J.M. Nanotechnology applications for food and bioprocessing industries. Biol. Med. 2016, 8, 1-6. [CrossRef]

32. Sawyer, D.J. Bioprocessing—No longer a field of dreams. Macromol. Symp. 2003, 201, 271-281. [CrossRef]

33. Manson, C. Regenerative medicine. The industry comes of age. Med. Device Technol. 2007, 18, 25-30.

34. De Vero, L.; Boniotti, M.B.; Budroni, M.; Buzzini, P.; Cassanelli, S.; Comunian, R.; Gullo, M.; Logrieco, A.F.; Mannazzu, I.; Perugini, I. Preservation, characterization and exploitation of microbial biodiversity: The perspective of the Italian network of culture collections. Microorganisms 2019, 7, 685. [CrossRef] [PubMed]

35. Schüngel, M.; Stackebrandt, E. Microbial Resource Research Infrastructure (MIRRI): Infrastructure to foster academic research and biotechnological innovation. Biotechnol. J. 2015, 10, 17-19. [CrossRef] [PubMed]

36. McCluskey, K. A review of living collections with special emphasis on sustainability and its impact on research across multiple disciplines. Biopreserv. Biobank. 2017, 15, 20-30. [CrossRef] [PubMed]

37. La China, S.; Zanichelli, G.; De Vero, L.; Gullo, M. Oxidative fermentations and exopolysaccharides Production by acetic acid bacteria: A mini review. Biotechnol. Lett. 2018, 40, 1289-1302. [CrossRef]

38. De Vero, L.; Bonciani, T.; Verspohl, A.; Mezzetti, F.; Giudici, P. High-glutathione producing yeasts obtained by genetic improvement strategies: A focus on adaptive evolution approaches for novel wine strains. AIMS Microbiol. 2017, 3, 155-170. [CrossRef]

39. McLaren, J.S. Crop biotechnology provides an opportunity to develop a sustainable future. Trends Biotechnol. 2005, 23, 339-342. [CrossRef] 
40. Jordan, N.; Boody, G.; Broussard, W.; Glover, J.D.; Keeney, D.; McCown, B.H.; McIsaac, G.; Muller, M.; Murray, H.; Neal, J.; et al. Sustainable development of the agricultural bio-economy. Science 2007, 316, 1570-1571. [CrossRef]

41. Jenkins, T. Toward a biobased economy: Examples from the UK. Biofuels Bioprod. Bioref. 2008, 2, $133-143$. [CrossRef]

42. Van Hal, J.W.; Huijgen, W.J.J.; López-Contreras, A.M. Opportunities and challenges for seaweed in the biobased economy. Trends Biotechnol. 2014, 32, 231-233. [CrossRef] [PubMed]

43. Kircher, M. The transition to a bio-economy: National perspectives. Biofuels Bioprod. Bioref. 2012, 6, $240-245$. [CrossRef]

44. Burton, D.M.; Love, H.A.; Ozertan, G.; Taylor, C.R. Property rights protection of biotechnology innovations. J. Econ. Manag. Strat. 2005, 14, 779-812. [CrossRef]

45. Bennett, A.B.; Chi-Ham, C.; Barrows, G.; Sexton, S.; Zilberman, D. Agricultural biotechnology: Economics, environment, ethics, and the future. Annu. Rev. Environ. Resour. 2013, 38, 249-279. [CrossRef]

46. Gavrilescu, M.; Chisti, Y. Biotechnology-a sustainable alternative for chemical industry. Biotechnol. Adv. 2005, 23, 471-499. [CrossRef]

47. Straus, J. Intellectual property rights and bioeconomy. JIPLP 2017, 12, 576-590. [CrossRef]

48. Aguilar, A.; Bochereau, L.; Matthiessen, L. Biotechnology as the engine for the Knowledge-Based Bio-Economy. Biotechnol. Genet. Eng. 2009, 26, 371-388. [CrossRef]

49. Hediger, W. Sustainable development and social welfare. Ecol. Econ. 2000, 32, 481-492. [CrossRef]

50. Pursula, T.; Aho, M.; Rönnlund, I.; Päällysaho, M. Environmental sustainability indicators for the bioeconomy. In Towards a Sustainable Bioeconomy: Principles, Challenges and Perspectives; Filho, W.L., Pociovălișteanu, D.M., Borges de Brito, P.R., Borges de Lima, I., Eds.; World Sustainability Series; Springer: Cham, Switzerland, 2018; pp. 43-61.

51. Rafiaani, P.; Kuppens, T.; Van Dael, M.; Azadi, H.; Lebailly, P.; Van Passel, S. Social sustainability assessments in the biobased economy: Towards a systemic approach. Renew. Sustain. Energy Rev. 2018, 82, 1839-1853. [CrossRef]

52. Goeschl, T.; Swanson, T. The Social Value of Biodiversity for R\&D. Environ. Resour. Econ. 2002, 22, 477-504.

53. Nissanke, M.; Thorbecke, E. Globalization, poverty, and inequality in Latin America: Findings from case studies. World Dev. 2010, 38, 797-802. [CrossRef]

54. Adams, W.M.; Aveling, R.; Brockington, D.; Dickson, B.; Elliott, J.; Hutton, J.; Roe, D.; Vira, B.; Wolmer, W. Biodiversity conservation and the eradication of poverty. Science 2004, 36, 1146-1149. [CrossRef] [PubMed]

55. Scopus. Abstract and Citation Database. 2019. Available online: https://www.scopus.com (accessed on 27 September 2019).

56. WIPO. Patentscope. Search International and National Patent Collections. 2019. Available online: https: //patentscope.wipo.int/search/en/search.jsf (accessed on 27 September 2019).

57. Journal Citation Reports -JCR-. Incites Journal Citation Reports. 2019. Available online: https://jcr.clarivate. com (accessed on 16 December 2019).

58. WIPO. International Patent Classification (IPC). 2019. Available online: https://www.wipo.int/classifications/ ipc/en/ (accessed on 19 December 2019).

(C) 2020 by the authors. Licensee MDPI, Basel, Switzerland. This article is an open access article distributed under the terms and conditions of the Creative Commons Attribution (CC BY) license (http://creativecommons.org/licenses/by/4.0/). 